to exercise the authority of masters greater than the D. of slaves to put up with their conditions as servants; 1324 MARSILIUS (DP, p. 57): For in those aspects which have been determined by law, the ruler's D. is to follow that legal determination.

(B) a formally unenforced social obligation 425 AUGUSTINE (CG, p. 860): Obviously, he will sit [on the judge's bench]; for the claims of human society constrain him and draw him to this D.; and it is unthinkable to him that he should shirk it; 1324 MARSILIUS (DP, pp. 10-11) ... because thus it seemed appropriate to all by a certain equity, not as a result of pro- longed inquiry, but solely by the common dictate of reason and a certain $\mathrm{D}$. of human society.

Notes:

Notice that duty has the connotation we might have expected from dominion. It is perhaps possible that Augustine prefers duty to dominion because of his fundamental distrust of humankind's impulses. He likely feels that men and women are unlikely to have the self-control described by Aquinas in Dominion $(\mathrm{C})$, and that if any good is to come of them, men and women must feel a sense of obligation, rather than empowerment.

See: VIRTUE

\section{Notes}

1. Much of my discussion here follows Ian Hacking's "Five Parables," in Philosophy in History, ed. Richard Rorty, J. B. Schneewind, and Quentin Skinner (Cambridge, England; Cambridge University Press, 1984), pp. 103-125, esp. 110-114. While, like Hacking, I am deeply suspicious of a problems approach to the study of philosophy, I also agree that the analytic skills gained by mastering this methodology can be valuable not as ends in themselves, but as means to other, more illuminating, intellectual projects to which the problems approach may be irrelevant.

\section{About the Author}

Darius Rejali teaches political philosophy and comparative politics at Reed College. $\mathrm{He}$ is the author of Torture and Modernity (Westview Press, 1994).

\title{
Iron Triangle Simulation: A Role-Playing Game for Undergraduates in Congress, Interest Groups, and Public Policy Classes
}

\author{
James W. Endersby and David J. Webber, University of Missouri-Columbia
}

D uring the winter semester of 1994, 130 students in three upperdivision undergraduate classes at the University of Missouri participated in a role-playing simulation of public policy formation in the U.S. Congress. This semester-long simulation enabled students to take a more active role in the learning process and to participate in an experience more closely resembling the real world of policy making.

This simulation involved three courses (Congress and Legislative Policy; Interest Group Politics; and Public Policy) taught by the two authors. Each of the authors independently reached the conclusion that the traditional lecture format in American politics courses often is not effective in providing students with an adequate understanding of the process underlying democratic decision making. High school civics and the evening news socialize undergraduates toward a passive study of political institutions. But the interaction and dynamic compromise inherent in the development of public policy can be lost using teaching strategies in which an instructor merely describes this dynamic relationship to students.

\section{Objectives and Structure of the Simulation}

Both instructors had employed role-playing simulations in previous courses but found that a political game lasting an hour or a week does not adequately provide students with the depth of knowledge obtainable in a lengthy simulation. Additionally, they believed that the relatively small scale of single-class simulations does not adequately reflect the uncertainty and complexity of the Washington environment. An alternative role-playing game was devised to introduce students to the process of politics. The goals of the simulation were to teach students how to cope with ill defined policy problems; to deal with a group policy-making process; and to improve written, oral, and electronic communication skills. Further, the instructors wanted to structure the simulation so that students still received much of the material presented in a more traditional course format, and they preferred that students would be graded on individual projects undertaken in a group process. Three contemporary public policy issues (environment, health care, and technology) were selected as the substantive policy focus for each of the three classes. The instructors coordinated their class schedules so that students could play their roles and interact with members of the other classes. Table 1 outlines the calendar for the three-course simulation.

Each student selected a role to play, subject to approval by the instructor. Students in the Congress class selected a House mem- 


\begin{tabular}{|c|c|}
\hline \multicolumn{2}{|c|}{$\begin{array}{l}\text { TABLE } 1 \\
\text { Outline of Simulation }\end{array}$} \\
\hline $\begin{array}{l}\text { Week During } \\
\text { Semester }\end{array}$ & Task for Completion \\
\hline Week 2 & Students select roles \\
\hline Week 4 & $\begin{array}{l}\text { Congress students complete Member and District Profiles } \\
\text { Simulation Kickoff Reception }\end{array}$ \\
\hline Week 6 & Interest Group students complete Interest Group Profiles \\
\hline Week 8 & Public Policy students complete Policy Memos \\
\hline & Interest Group students complete Issue Positions \\
\hline & Congress students, complete Memo of Policy Concerns \\
\hline & Proposed Legislation drafted \\
\hline Week 9 & Each committee elects chair and ranking minority member \\
\hline Week 10 & $\begin{array}{l}\text { First Committee Meeting-Introduction of Legislation and Setting of } \\
\text { Committee Agenda }\end{array}$ \\
\hline Week 11 & Second Committee Meeting-Testimony \\
\hline Week 12 & Third Committee Meeting-Markup and Votes \\
\hline Week 13 & Mock Congressional Session (Friday and Saturday) \\
\hline Week 14 & Debriefing Paper Due-"Lessons of the Congressional Simulation" \\
\hline
\end{tabular}

ber from a list provided by the instructor. The list of alternative members reflected the regional, party, gender, and policy interests of the 103rd Congress but excluded well-known members and the entire Missouri delegation. Each student in the Congress class prepared a member and district profile and was expected to play the role of a member representing the district of the member selected.

Members of the interest group class became lobbyists for an organization and prepared a paper on the organization for which they worked and the interest(s) it represents. Students represented the full range of organizations including economic organizations (American Medical Association, Electronic Industries of Japan, AFL/CIO, Business Roundtable), public interest organizations (National Organization for Women, National Rifle Association, Natural Resources Defense Fund, League of Women Voters), and governmental lobbies (National Governors' Association). ${ }^{1}$ Those in the policy class selected roles as committee staffers or deputy directors of executive agencies active on the policy issues selected and prepared memoranda on important issues in one of the three policy areas. In the preparation of papers, each student incorporated material from the readings and lectures and used their research findings as background material for participation in the subsequent simulation. ${ }^{2}$ The first formal meeting, an introductory evening reception, allowed students to meet other participants of the simulation. Lists of students and their roles were distributed at the meeting. ${ }^{3}$ In addition, several speakers - state legislators, lobbyists, and staffersaddressed the students and described their experiences in the actual law-making process.

After the initial meeting, students were given several weeks to prepare drafts of bills, policy memos, position papers, and other releases. This information was distributed to all participants in several ways.

First, a campus development grant made it possible to photocopy student papers and to distribute them to students in all three classes. Second, all students were provided with a mainframe computer account and were encouraged to use electronic mail to contact others. A simulation listserv (an "electronic bulletin board") was maintained for the use of all participants. Many social science students had never used a computer for any function beyond text processing, and we were surprised at how eager political science undergraduates were to learn computing technology for both e-mailing and "gophering." Third, four students registered in dual classes suggested publication of a newspaper on the simulated events. ${ }^{4}$ Other students supplied press releases and other informasome interest group representatives even purchased advertising space tion to these media representatives; in the newspaper. Finally, many participants organized formal or informal meetings with classmates, especially those from other courses.

Regular class sessions in all three courses, particularly in the early weeks of the semester, were organized in a traditional reading/lecture format. Students were required to take midterm and final examinations. Simulation research and activity replaced outside projects typically assigned by the instructors. Students prepared papers, but these assignments were limited to information-gathering for their roles in the simulation. Participation in the simulation accounted for a substantial portion of a student's course grade. ${ }^{5}$ Students did not have an outside lab, but the number of regular class meetings was reduced to substitute for time spent in the simulation portion of the course. Although several hours of class time were used for discussion and preparation for key events in the simulation, all of the official sessions of the simulation were held in the evening outside regular class time. Meetings were scheduled on campus in rooms that contributed to experiencing the environment of a committee room or of the House Chamber.

\section{Formal Meetings of the Simulation}

The Congress was organized as the House of Representatives with three standing committees: Environment, Health, and Technology. Few restrictions were placed on this legislative process, ${ }^{6}$ and many of the participants became expert parliamentarians. Each committee held three concurrent meetings over five weeks. Members could introduce bills at any time by filing a bill with the committee chair and one of the instructors. During the first set of committee meetings most of the pending bills were introduced and the upcoming agenda was set. Testimony was heard at the second set of committee meetings with interest group representatives and bureaucratic officials testifying before committees about the merits of proposed legislation. 
Markup of legislation was conducted at the third and final prescheduled committee meeting. During this meeting, a majority of the committee could send the current form of the bill to the floor.

A Rules Committee was established to set the floor agenda and limits on debate. Failure of the Health Committee to report a certain comprehensive health care bill led to a discharge petition. Republicans maneuvered to delay consideration of most liberal legislation.

The overall effect was one of (realistic) legislative gridlock.

The final event, a mock session of Congress, took place over a twoday weekend. Volunteers served as parliamentarian, House clerk, and pages. Congress adjourned several times and allowed additional committee meetings over the weekend. Generally, participants followed congressional norms and procedure. ${ }^{7}$ On the second day of the legislative session, students in the policy and interest groups classes became Senators, considered legislation passed by the House, and met with Representatives in conference committees. Fifty-seven bills were introduced throughout the simulation, and 13 bills passed in the House of Representatives. ${ }^{8}$ Despite frustrations over the legislative process, most student participants were actively involved in the proceedings. The final written assignment, due several days later, for students in all three classes was a debriefing paper, relating experiences in the simulation to the material covered in class readings and lectures.

\section{Evaluation of the Simulation}

At the end of the semester, surveys on the simulation were distributed with course evaluations. Ninety-three surveys from the three classes were returned (a response rate of $70 \%$ ). Generally, participants found the iron triangle simulation to be a pleasant learning experience. Table 2 reports the responses to some of the questions on the survey.

A large majority rated the multiclass simulation as a success. Most

\begin{tabular}{|c|c|c|c|c|c|}
\hline Item & $\begin{array}{l}\text { Strongly } \\
\text { Agree }\end{array}$ & Agree & Uncertain & Disagree & $\begin{array}{l}\text { Strongly } \\
\text { Disagree }\end{array}$ \\
\hline $\begin{array}{l}\text { The simulation was a useful } \\
\text { learning tool. }\end{array}$ & $54 \%$ & $31 \%$ & $4 \%$ & $11 \%$ & $0 \%$ \\
\hline The simulation was enjoyable. & 36 & 34 & 17 & 9 & 4 \\
\hline The simulation was realistic. & 38 & 36 & 17 & 6 & 3 \\
\hline $\begin{array}{l}\text { The simulation helped me learn } \\
\text { more about politics. }\end{array}$ & 45 & 33 & 13 & 8 & 1 \\
\hline $\begin{array}{l}\text { The simulation caused me to get } \\
\text { more involved in the class. }\end{array}$ & 38 & 38 & 15 & 8 & 2 \\
\hline $\begin{array}{l}\text { I prefer the traditional lecture } \\
\text { format to this simulation. }\end{array}$ & 14 & 5 & 14 & 30 & 37 \\
\hline $\begin{array}{l}\text { This simulation should be offered } \\
\text { in this course in the future. }\end{array}$ & 52 & 26 & 9 & 10 & 4 \\
\hline $\begin{array}{l}\text { I would like to take a course with } \\
\text { this kind of simulation again. }\end{array}$ & 38 & 28 & 16 & 12 & 6 \\
\hline
\end{tabular}

students found that the experience was enjoyable and increased their level of class involvement. A majority of the students surveyed agreed with the statement "My portrayal of my role was realistic," and only a minority agreed that "Some of the other characters I depended on were not realistic." The majority expressed willingness to participate in another simulation and preferred our experiment to the traditional lecture format of political science classes. We were most impressed with the strong consensus that the simulation provided a productive educational experience. Over three quarters of students agreed that the simulation was a useful learning tool, that it encouraged learning about politics, and that they believed simulations should continue as a course requirement.

In response to open-ended questions, students positively evaluated the simulation. Many also listed a number of drawbacks to the simulation. Institutional complaints seemed most common: Congress was too independent (from the wise thinking bureaucrats and lobbyists), staffers and interest group representatives were unwilling to work on important issues (unlike the selfless legislators), and participants who were not members of Congress could not control the process. This last observation was frequent and revealing; one problem with the simulation was the lack of an electoral connection. Members of
Congress, in the simulation, had no constraints on their behavior outside legislative party organization.

Students' assessments of their own performances were somewhat mixed. In open-ended questions, several students complained that the simulation was too time-consuming. Many more, however, responded that they should have spent more time preparing bills and memos, using the computer, attending meetings, and so forth. One student wrote: "I was surprised at how well this whole thing went. I have been in several group projects throughout my college career and none of them went the way this one did. Usually, everyone just sits there, someone gets picked to do all the work, and then everyone complains they don't learn anything. But since our individual grade depended on how well we participated, we all got down to business and worked. ... I really got into the role. ... This was one of the few times I felt like I was really getting something for the money I dish out every semester."

Students were also asked to make a general assessment of the role-playing experience. Nearly $40 \%$ of students responding rated the overall simulation as 'excellent'; another $35 \%$ gave a 'good' rating. Those students expressing reservations with the simulation often held what we believe were unrealistic expectations: that communicating with public officials for large blocks of time is easy; that 
reaching consensus on volatile issues was frequent; that public policy issues are simple. We were reassured that even these complaints demonstrated valuable lessons learned.

Responses to the open-ended questions confirmed our observation that most students were interested and motivated by the experience. A student in the Public Policy class wrote: "I felt like I was watching C-SPAN so this simulation must have been authentic. Perhaps I was too hard on the Congress class. They surprised me by just how much they knew about procedure. They conducted themselves like the important policy makers they were emulating." Another student maintained: "The simulation, I believe, was surprisingly successful. I had not anticipated that people would have become so involved early in the process. ... I was also surprised that the simulation was so realistic, based on what I had learned in class and, in large part, from Price's book [The Congressional Experience]. I had assumed that there would be superficial legislation passed and weak attempts at humor throughout the simulation. The bills submitted and passed were basically valid and timely, and the comedians few."

Role-playing simulations are useful instructional devices which can give students a more direct experience with course material. The macro-simulation combining three distinct classes provides an inter- esting alternative teaching method for political science undergraduates. Students, as well as instructors, must be willing to invest time and make advance preparations for participation in a macro-simulation. But the results can be rewarding.

\section{Notes}

The authors express their gratitude for assistance, support, and resources provided by the University of Missouri Alumni Association, the College of Arts and Science, the Department of Political Science, and Donna Hanly.

1. Care must be taken in the selection of the roles because students tend to uncharacteristically choose public interest organizations over more traditional lobbies. Competing interests (the NRA and Handgun Control, prolife and prochoice lobbies) significantly add to realism.

2. Once the simulation began, the instructors were reluctant to interfere in the decision-making process and restrict activity to the three policy areas. After preparation of research papers, however, most students naturally stayed within these confines and offered few bills or amendments outside the areas of environment, health, and technology.

3. Some students were initially impressed by the large number of people attending the introductory meeting. Seeing nearly a hundred other students from other classes seemed to instill feelings that this class project was important.

4. The paper, Simulation Weekly, had four editions and a post-simulation "extra" listing final outcomes of proposed legislation.

5. About $40-50 \%$ of a student's course grade depended on simulation-related activity. In the Interest Groups class, for instance, $20 \%$ of a student's grade came from the research paper (which served as the basis for that student's role), $20 \%$ from simulation participation (activities outside the classroom), and $10 \%$ from class participation (a portion of which dealt with the simulation).
6. The absence of fiscal constraints, for example, led the instructors to insist on funding limitations. Each bill had to fund itself (through specific budget cuts and so forth). But even this was done indirectly. The OMB and the White House issued electronic press releases, and a simulated President Clinton was quoted in Simulation Weekly as saying that he would veto any House legislation that raised taxes or the deficit.

7. One student did initially object to opening daily House sessions with a prayer but was satisfied when assured that this is a regular practice. The instructors were puzzled by the Representatives' refusal to leave their seats on the floor of the chamber even during one-minute speeches and legislative debate on predetermined votes. This curious phenomenon severely restricted lobbyists and staffers from contact with members of Congress as they were not allowed on the floor. On the other hand, members voluntarily met congressional norms. For instance, former President Richard Nixon died on the weekend of our simulation. Republicans wore black corsages after the announcement, and the House held a moment of silence during the Saturday session.

8. Four of these bills passed the Senate. A few bills were defeated in the House or failed to reach a floor vote. Most legislation, however, died in committee.

\section{About the Authors \\ James W. Endersby is an assistant professor of political science at the University of Mis- souri-Columbia. His publications include many articles on interest groups, political participation, and the legislative process.}

David J. Webber is an associate professor of political science at the University of Missouri-Columbia. He served as a APSA Congressional Fellow during 1992-93 and his research interests include public policy, biotechnology policy, and the use of policy information in the policy-making process.

\title{
The Quote Analysis: Teaching Political Science Students to Read with Focus
}

\author{
Charles Hersch, Cleveland State University
}

How often have we questioned our students about a book or article they have read, only to find that they cannot state the main arguments or even say what they have found interesting? Our first assump- tion might be that they have not done the reading, but frequently this turns out not to be the case. Instead, the problem lies with how they have read. Too often, when confronted with a reading assign- ment, students let their eyes run over the page line after line without having a clear sense of what is important or how it might relate to their lives. This is especially true in political theory courses, where stu- 